\title{
'HIDDEN MESSAGES' EMERGING FROM AFROCENTRIC MANAGEMENT PERSPECTIVES
}

\author{
H van den Heuvel, Vrije Universiteit, Dep. of Culture Organisation en Management, Amsterdam
}

\begin{abstract}
Purpose: This paper aims to examine how 'African management' discourse has emerged in South Africa. Altogether, it has stimulated debates - sometimes in controversial ways - on 'taboo issues', e.g. relating to 'cultural diversity' and 'ethnicity'. The stimulation of such debates within organisations is probably a more valuable contribution than a static, essentialised 'African identity' that it proclaims.
\end{abstract}

Design/Methodology/Approach: The paper draws on a qualitative research project conducted in South Africa in 2003-2004. Its relevance lies in gaining in-depth insights into ('non-western') local management discourse. It seeks to contribute to the body of knowledge on political and cultural contexts in which South African organisations operate, and how they impact on local management perspectives, and vice versa.

Findings: The research findings make clear how and under what circumstances 'African management' discourse has come about in South Africa, and how it could be interpreted.

Implications: 'African management' advocates allegedly attempt to revise dominant management thinking and promote 'humane-ness' and participatory decision-making in South African organisations, in search of a contextualised management approach. Amongst others, it has produced new meanings of 'Africanness' and has opened up space for 'hidden messages', resentments and aspirations to become openly articulated. This throws another light on phenomena such as cultural diversity and ethnicity that usually tend to be 'neutralised'. This may turn out to be far healthier for blooming organisational cultures in South Africa than relentlessly hammering on prescribed 'corporate values'.

Originality/Value: This paper informs the reader in detail about the emergence and evolvement of 'African management' discourse in South Africa. It is a unique attempt to develop an interpretative viewpoint on this intriguing phenomenon that offers a potentially valuable contribution in reading cultural and ethnic identities within organisations.

Key words and phrases: Transition, organisational culture, identity, Afrocentrism, cultural diversity, ethnicity.

\section{INTRODUCTION}

This research paper describes the emergence of 'African management' discourse in South Africa, which has evoked a debate to revise dominant management thinking and promote 'humane-ness' in organisations, in search of a contextualised management and leadership approach. In the course of years, it appears to have produced new meanings of 'Africanness', putting emphasis on 'hardnosed decision making' and performance, exposing a (South) African identity in-the-making that matches well with capitalist economic development. Introducing 'ubuntu' as a key concept, simultaneously the discourse has opened up space for debates that were previously unheard of, in which a long history of 'coercive labour' and its impact on managerial conventions and organisational cultures tend to be asserted. Often performed in a dramatised manner, 'African management' workshops frequently provoke emotional debates, in which resentments and aspirations are openly articulated. 'African management' advocates provide a stage for such events and - though perceived by many as 'dubious' - these experiences may help revealing cultural meanings that otherwise tend to be overlooked, or consciously avoided. The facility to stimulate such dialogues on controversial issues in formal organisational contexts is possibly the most valuable contribution of 'African management' discourse to South Africa's business, probably more than the proclamation of a static, essentialised 'African identity'.

Since more than 15 years now, dominant management discourse in South Africa has been contested by a locally emergent perspective that has come to be known as 'African management'. Lovemore Mbigi, originating from Zimbabwe and executive director of Rainmaker Management Consultants based in Johannesburg, is one of its prominent 'producers' and advocates. He actually claims to have 'branded' the term 'ubuntu' in relation to (African) management, of which 'umunhu' 
would be the equivalent in his Shona mother tongue, which supposedly stands for the essence of being human, shared humanity or 'humane-ness'. Roughly translated it would mean collective morality, sharing, and unconditional mutual solidarity. Could South African business and management actually gain something from a local perspective that puts so much emphasis on 'African culture' and 'traditional values'? Does the 'African management' approach reveal an indigenous 'high performance' business model? Or, is it merely a bizarre folkloristic notion of Africa's 'cultural heritage', based on a largely imaginative, romanticised past? These questions are addressed in this paper. Firstly, an outline of how the argument is structured is given.

\section{BACKGROUND TO THE STUDY}

To be able to understand what 'African management' philosophy is about, it is helpful to go back in time. At the end of the 1980s, a transformative strategic alliance was formed between a visionary business elite and leaders from African resistance movements. From this initiative, an 'African management' vision arose, with a strong Afrocentric orientation. In the following paragraphs, this process is described and analysed, from a discussion of the Consultative Business Movement (CBM), proposed pleas for 'paradigm shifts' in management, the role of the South African Management Project (SAMP) up to the dawn of an 'African management' movement. Subsequently, Eskom's utilisation of the 'African Business Leadership' concept is reviewed, illustrating a contemporary appropriation of 'African management' philosophy. Eventually, an attempt is made to develop an interpretative perspective, with a specific focus on addressing issues around cultural diversity and ethnicity in South African organisations.

Would the significance of an Afrocentric approach to management and organisation lie in a fixed focus on 'Africanness', or rather in the contestation of organisational orthodoxies and breaking of taboos? This specific approach is one of several attempts to explore questions of social identity in South African organisations, and (a reconstructed) history plays an important role in processes of identity formation. Undoubtedly, history has left its traces on organisational cultures in South Africa, which can be experienced to date. To a certain extent 'African management' discourse could be understood as a response to South Africa's long history of 'coercive labour' as a consequence of 350 years of inequality (Terreblanche, 2002). 'South African workplaces are burdened with legacies of division and conflict that were entrenched during the fifty years of apartheid's political economy', David Dickinson wrote as the first sentence of a paper about workplace change in the 'New South Africa' (Dickinson, 2005:287). Some analysts observe a tendency towards new authoritarianism in the South African workplace (e.g. Webster \& Von Holdt, 2005:31). In response to all this, supposedly 'African management' advocates not merely call for a participatory management style and a humanistic approach to leadership, but also demand recognition of (collective) past experiences of humiliation, deprivation, and discrimination. Such orientation might run the risk of becoming trapped in a neurosis of victimisation: a paranoid reading of history [...] presented as "democratic", "radical" and "progressive" discourse of emancipation and autonomy' (Mbembe, 2002:252). This risk is there, but as is argued here, in the end the discourse may well move beyond this point.

Engagement with key Afrocentric viewpoints by means of an 'African management' philosophy could help detecting 'hidden messages', prompting specific debates on rather precarious issues relating to experiences of the past, for instance (perceptions of) alienation, discrimination, anger, 'race' and 'tradition'. The latter is a thorny one, because - like ethnic and tribal identities - these notions are considerably bound up with former colonial and apartheid strategies (Mamdani, 1996 and Vail, 1991). Issues as these are not often freely discussed in formal organisational contexts. Therefore, beyond its most evident features, an 'African management' philosophy may encourage a special awareness among top-managers and business leaders to engage in a serious dialogue on such particularly sensitive issues. Precisely the importance of the historical dimension, drawing attention to human suffering and experiences of humiliation associated with the past, is often overlooked in evaluations of 'African management' discourse in contemporary business practice. Thus, it might be seen as a (temporary?) confrontational stage to eventually develop into historicised and contextualised South African perspectives and home-grown 'synergetic' styles of leadership. The argument outlined here will be elaborated in the following sections. 


\section{A MOOD OF CHANGE: THE CONSULTATIVE BUSINESS MOVEMENT}

'African management' discourse emerged in South Africa in turbulent times. The late 1980s and early 1990s evoked on the one hand feelings of fear about the changes that were about to occur and on the other hand a great deal of optimism about bright future prospects. Likewise, for the business sector there was reason for concern, but also excitement, at least among imaginative mavericks and the more proactive forward-looking sections of the South African corporate sector.

In 1988, after a lengthy period of tough talks between about forty business leaders, academics and professionals and an equal number of representatives of democratic mass movements at the legendary 'Broederstroom meeting', the Consultative Business Movement (CBM) was launched. CBM aimed 'to make a difference' by mobilising business 'as a major agent for change' (Nel, 1988:35). For one of the first times ever, business representatives met with leaders of African resistance movements, e.g. the Congress of South African Trade Unions (COSATU), the United Democratic Front (UDF) and the National Unions of Mineworkers (NUM). The executives of a core group of South African companies, e.g. AECl, First National Bank, Southern Life, Tradegro and Trust Bank, and individual businessmen wished to establish relationships with them. ${ }^{1}$ Also Engen, Eskom, Gencor, Nampak, Shell, PG Bison, Protea Assurance and others joined in (Eds, Alberts, Coetsee, Coleman, Eloff, Marsden \& Payne, 1993). Christo Nel was one of CBM's co-founders. Christo Nel was one of CBM's co-founders and became its executive director. ${ }^{2}$ Later Theuns Eloff took over. Albert Koopman was also one of the founding members. A few years down the line, Koopman would play a prominent role in the birth of 'African management' discourse.

At the 'Broederstroom meeting' business leaders were free to express their fears, e.g. about dreaded 'communist take-overs' (Nel, 1988:35). On their turn, black political leaders articulated their distrust of white business leaders, suspecting them of conspiring with the apartheid state. On both sides, a difficult process of exchanging views, perceptions and grievances took place. Mostly, business leaders were blamed that they had been 'passive bystanders who claim the comfort of "not wanting to be politically involved"' or at best rely on 'ad hoc, unilateral actions' (Nel, 1988:36). The consultation revealed somewhat painfully 'the political and social illiteracy' of a considerable number of white entrepreneurs.

CBM turned out to be a sustainable initiative. It was active during a number of years and has been considerably supportive of the process of non-violent transition. It advocated 'broadening the ownership and management base' and suggested amongst other things 'collective participation in decision making' on different levels (Alberts et al., 1993:32). This would imply co-responsibility of employees and management in decision-making and aligning the company strategy with the process of changing business practices. Key issues were building trust, creating a shared value system, encouraging equal employment opportunities and replacing hierarchical organisational structures and autocratic management styles with 'legitimate business practices'. Furthermore, a component of 'business acculturation' was proposed, taking cognisance of the 'fears of whites' and the 'aspirations of blacks'.

\section{Paradigm Shifts}

The stream of popular management literature published in South Africa in that particular period reflected the changing political mood and business realities. Several authors utilised an inspirational, high-energy type of 'transformation language', propagating new approaches to business and management (e.g. Eds, Koopman, Nasser \& Nel, 1987; Lascaris \& Lipkin 1993; Nasser \& Vivier, 1995 and Hunt \& Lascaris, 1998). 'New' management philosophies were explored, and a need for 'paradigm shifts' in management thought was expressed, putting emphasis on 'leadership' and 'mentorship' instead of 'management' in a strict sense. 'African management' was part of this flow of optimistic and refreshing management visions and new buzzwords. The launch of the African Renaissance project somewhat later more or less coincided with and reinforced emergent 'African management' thought. Parallel to this, the notion of 'ubuntu' also cropped up,

\footnotetext{
1 'Businessmen hold talks with extra-parliamentary groups' Weekend Argus 13 August 1988.

2 'Leadership expert migrates from Stellenbosch to corporate heartland' Sunday Times Business News 30 June 2002. Christo Nel is head of the Center for Leadership Studies at the University of Stellenbosch Business School (Source: www.usb.sun.ac.za/USB/People [accessed 20 July 2004]).
} 
which became appropriated in management discourse.

In this stream of 'new' management visions, South Africa's history of labour relations and the impact of colonialism and apartheid were raised, along with the need for nation building, also in the realm of management and organisation. These aspects seem to be often overlooked in contemporary management practice, as if the majority of the South African workforce never even had a history. The notion that (black) Africans were 'a people without history' was also deep-rooted in colonial discourse.

A change of mood and a mood of change created - perhaps temporarily - an open space for public debate about the future role of business in society, giving room to voices that were seldom heard before. A small but notable section of the private sector and the academic community started imagining a more humane South Africa, without institutionalised racial discrimination.

How 'African management' vision came to be known as such was largely attributable to the South African Management Project, at Wits Business School in Johannesburg. Peter Christie, Ronnie Lessem, and Lovemore Mbigi were the driving force behind this initiative.

\section{WITS' SOUTH AFRICAN MANAGEMENT PROJECT}

The headlines of the South African newspaper Sunday Times on 21 March 1999 brought a somewhat unusual report: "Darkies' and 'Boere' slug it out" and in the subtitle "...motivational speaker gets lifelong racists to kiss and make up in Post Office's mass bonding session." The motivational speaker was Professor Lovemore Mbigi. He was one of the 'inventors' of 'African management' thought in South Africa. Born in Zimbabwe, between three and sixteen years old he was for a large part brought up in the rural areas by his grandmother, who happened to be the Shona Rain Queen. She was a medium of the spirit of Dembetembe, responsible for the well-being of the Vahera people (Mbigi, 1994:78). From his grandmother he got his 'tribal training' and learned about local Shona traditions and oral histories. ${ }^{3}$

Another key person in the emergence of 'African management' was Ronnie Lessem, a son to Abraham Lessem who had founded a manufacturing company in the mid- $20^{\text {th }}$ century in what then was Rhodesia. Lessem studied at Harvard Business School and obtained his PhD at City University in London. He became a lecturer at the University of Zimbabwe, where Mbigi was 'his brightest student' at the time. Mbigi liked to engage in fierce debates, displaying his scepticism about 'western management' and challenging Lessem to take African concepts into account. This inspired Lessem to develop African management ideas. Approximately in 1991, after moving from Zimbabwe to South Africa, Lessem got involved in a 'think tank' on management issues, which was called the South African Management Project (SAMP). He desperately wanted to invite Mbigi to this 'think tank', because of the latter's unconventional views on management in an African environment and perhaps even more because of his experimenting as director and business consultant in Zimbabwe, allegedly inspired by his traditional Shona upbringing and his background as 'a peasant boy'. Mbigi is still proud to be called 'a tribesman'. SAMP was initiated at Wits Business School (WBS) of the University of Witwatersrand in Johannesburg. Its purpose was:

...to articulate and develop approaches to management that are relevant to the context in which South African business leaders are and will be managing their operations in the future. (Binedell, 1994:11)

SAMP organised several activities such as workshops, lectures, debates, and research. Peter Christie was one of the initiators. His motivation was the search for a contextual approach to management in South Africa. Christie felt that the possibilities of developing a locally embedded management approach should be looked into that would fit the specific South African situation. He was inspired by the work of the anthroposophists Rudolf Steiner and Bernard Lievegoed, who basically believed in spontaneous development in organisations, not too much bothered with strict rules, procedures, and formal structures. As a part-time lecturer at WBS, Christie had several discussions with colleagues, especially Nick Binedell, who became director in 1992, and he was immediately interested since the management of African organisations has traditionally been

\footnotetext{
${ }^{3}$ Interview with Lovemore Mbigi on 28 June 2003.
} 
largely neglected by the mainstream business literature' (Eds, Christie, Lessem \& Mbigi, 1994:Preface). He managed to raise some funds and then the ball started to roll. As Christie and Binedell described it in retrospect, the SAMP initiative came into existence 'almost by coincidence' in a time when the business community was very confused about future developments. ${ }^{4}$ In the 1990s, Binedell happened to be also involved in CBM: 'Our concern was more about corporate management and consiencising South African executives, white managers, about how to engage in a South African or an African reality'. ${ }^{5}$ SAMP brought together a unique group of people with different backgrounds - academics, managers, and business consultants from South Africa and Zimbabwe - exchanging new ideas on 'how things could be done differently' in South African organisations. In 1992, a two-day workshop was organised in Johannesburg, called Theory of the African Firm. Nick Binedell came up with this title. ${ }^{6}$ He felt that it was time to rethink fundamentally organisation and management concepts in South Africa:

...what was very clear at the time was [...] that the dynamics of South Africa and African culture were not really being addressed in organisations. ${ }^{7}$

In his view, South Africa's economy could only be successful if 'society approves of the actions and role of business' (Binedell, 1994:9). The Theory of the African Firm workshop can definitely be seen as the cradle of Afrocentric management discourse in South Africa.

\section{THEORY OF THE AFRICAN FIRM WORKSHOP}

With the Theory of the African Firm workshop, the seed of 'African management' was sown and SAMP was its nursery. There were debates about how changes in South African society would affect business and organisations. Among the main contributors were Reuel Khoza, Albert Koopman, Ronnie Lessem, and Lovemore Mbigi. Albert Koopman and Christo Nel were also invited, because they were known for their leading role in CBM. Both were partners in the consultancy firm Interdependence and Transformation in South Africa (ITISA). Binedell felt that 'Albert Koopman was really the originator of ideas that I thought really resonated authentically the South African story'. In 1991, Koopman published Transcultural Management, in which he described how he had tried in the 1980s to transform his company Cashbuild, a wholesale cashand-carry retailer in building materials, by introducing participative management principles and radically changing its management philosophy. Ronnie Lessem described this philosophy as 'industrial democracy' (Koopman, 1991:Foreword). Koopman as managing director entirely opened himself up to his employees, and to their cultural orientations. As a self-educated Afrikaner entrepreneur, he explicitly identified himself as a 'White African'. ${ }^{8}$ He was very eager to learn about 'African culture' (Koopman, 1991:60). Above all, so he claimed, this was mainly for his personal evolution and enlightenment. At a conference in 1991 in Midrand, Koopman explained that 'ubuntu' was 'more of a spiritual process'. ${ }^{9}$ He went on: 'It is concerned with what is fair and unfair, rather than with what is right and wrong' ${ }^{10}$. Others interpreted the event as a 'call for humane business'. ${ }^{11}$ Essentially, transculturalism was in Koopman's view about the freedom of enterprising: 'a spiritual human value manifested in the nature of work within communities' (Koopman, 1991:88). While Koopman valued the search for identity of workers and industrial democracy, others talked of the importance to develop 'an authentic genre' of local management, and of the need to create an 'own business identity' (Lessem \& Nussbaum, 1996:13).

In 1993, a book was published that came out of the 1992 workshop, called African management. Philosophies, Concepts and Applications (Christie et al., 1994). With this book, the concept was definitely launched. To Reuel Khoza, one of the involved intelligentsia of the first hour, the notion of

\footnotetext{
${ }^{4}$ Interviews with Nick Binedell on 31 July 2003 and 2 September 2003 and with Peter Christie on 24 October 2003 and 28 April 2004.

${ }^{5}$ Interview with Nick Binedell on 31 July 2003.

${ }^{6}$ Interview with Peter Christie on 28 April 2004.

${ }^{7}$ Interview with Nick Binedell on 31 July 2003.

${ }^{8}$ Interview with Albert Koopman on 26 June 2004.

${ }^{9}$ This conference was organised by the Black Management Forum, the Institute of Directors SA and the Economic

Community of Southern Africa.

${ }_{10}^{10}$ The Daily News, 11 November 1991

${ }^{11}$ Sowetan, 31 October 1991.
} 
'African culture' was pertinent in the search for a contextual approach in leadership and management:

South Africans had better stop behaving as though they were an outpost of Europe or somebody else. We have to get to know ourselves and begin to use our existential reality as a departure point. (Khoza, 1994:118)

It can be confidently assumed that Khoza was the first one in South Africa to introduce the idea of 'ubuntu' explicitly in relation to management that he associated with supportiveness, cooperation, solidarity, community, in short with 'communalism', which 'with diligent cultivation it should be extendable to the business corporation' (Khoza, 1994:122). Later on, Mbigi claimed that he had actually introduced and branded this concept, although he acknowledged Khoza for bringing up the Zulu term. ${ }^{12}$ Khoza has been influential in the co-production of a South African version of Afrocentric management and leadership thinking over an extraordinary wide span of time (Prinsloo, 1998 and Mangaliso \& Nkomo, 2001).

Once the concept was launched, it created the ground for other developments in the field: the distribution and utilisation of these new insights. Several companies were eager to involve 'African management' advocates to 'try out something new', something different. Mbigi, Koopman, Lessem and others participated in several road shows, e.g. for Nampak and for the South African motor dealers association in cooperation with Wesbank. Looking back, they experienced these road shows as 'fun'. ${ }^{13}$ However, they also dealt with quite serious political issues, making managers aware of the problems and challenges of the country and the urge for drastic business transformation.

From a reconstruction of the emergence of Afrocentric management approaches in South Africa, we will now review a contemporary appropriation of 'African management' philosophy. Eskom's utilisation of the 'African Business Leadership' concept serves as an illustration of this.

\section{ESKOM'S CONCEPT OF 'AFRICAN BUSINESS LEADERSHIP'}

Presently, Eskom as a 'public enterprise' seems to be making headway in the institutionalisation of the discourse, by facilitating yearly 'African Business Leadership' forums and supporting a Leadership Academy in the same spirit. They are doing so quite confidently, apparently not bothered by the fact that it would still be a marginal discourse, or by the fact that the subject is not included in the curricula of tertiary educational institutes in South Africa, such as business schools. Eskom has been undertaking bold initiatives on its own to institutionalise an 'African management'/'African (Business) Leadership' vision. This is precisely what Lessem and Mbigi have been longing for so badly.

In recent years, partly also due to Eskom spokespersons, interpretations of 'ubuntu' and management have been (re)formulated in more 'hard-nosed' terms than in the early 1990s. Their interpretations of 'African (Business) Leadership' are not characterised by a soft humanistic notion or in terms of 'black victimhood' of any sort. Yet it is all about social identity, creating an African corporate identity in South Africa, which goes together well with rapid corporate expansion throughout Africa. Perhaps somewhat surprisingly, it also matches with a classical (so to say 'typically American') approach to 'a strong corporate identity'. This is confirmed by the fact that IBM South Africa has been assisting Eskom to reinforce its corporate identity, while IBM is usually not particularly supportive of developing a sense of national identity. ${ }^{14}$ In other words, Eskom combines in its leadership vision African values such as 'ubuntu' with ambitious business targets and regular performance reviews, aided by an American multinational company to create 'a strong corporate culture'. The overall aim is to become 'a global organisation, to be an African leader' that would be 'recognised as a leader generally from the global perspective'.

In his capacity as non-executive chairman of Eskom, 'Africa's largest electricity utility', Reuel Khoza has been promoting the incorporation of 'African values' in the workplace. He is a frequent speaker

\footnotetext{
12 Interview with Lovemore Mbigi on 14 August 2003.

${ }^{13}$ Interviews with Lovemore Mbigi in 28 June 2003 and with Ronnie Lessem on 23 June 2004 respectively.

${ }^{14}$ Interview with Mpho Letlape on 9 December 2003.
} 
at conferences and business meetings. In his view, the 'ubuntu' concept would facilitate teamwork and innovation. Moreover, it is said to advocate integrity and humbleness and create a sense of self-esteem.

I draw heavily on the work of others and base myself on the realisation, shared by many, that businesses seeking a cultural identity, starting with our own in South Africa, can translate Ubuntu into a principle of workplace cooperation and thus make it a living business process. The defining features of Ubuntu in organisational life are probity, integrity, compassion and humility, all grounded on the self-worth that comes from belonging to a community. ${ }^{15}$

Chief Executive Officer of Eskom Holdings Limited, Thulani S. Gcabashe stated that he was confident that 'an African leadership approach' would be accepted worldwide. ${ }^{16}$ Gcabashe emphasised the scale and magnitude of Eskom's enterprises, with its approximately 32,000 employees, operating in 30 countries on the African continent, contributing about $50 \%$ of the total energy production in Africa:

We need to both copy and innovate technologies and combine these matters with African values. In a world of globalisation, we need to see what is in common with us and on a global level. There is internationally recognition and respect for African values. [...] Would things be done differently, better, in South Africa with black leaders in politics and in business, with positive results? This inspired Eskom to take up the 'African leadership development initiative' and encourage a process of introspection, looking inwardly. The introspection comes with studying leaders such as Biko and Mandela.

Khoza's and Gcabashe's exposés on 'African (Business) Leadership' issues highlight the necessity to create a sense of self-consciousness and self-confidence. Reuel Khoza has repeatedly proclaimed that Africans should 'stop blaming' others and start becoming 'world-class' and high performing (e.g. Khoza, 2003:1-2). Thus he helps to create an emerging sense of 'Africanness' that would reveal itself particularly in the practice of consultation and in valuing cultural diversity, but not in the least - in tangible business achievements. In fact, Khoza advocates a (South) African (business) identity in-the-making and 'as performed', while he repeatedly refers to the inheritance of 'past heroic kings' and presidents that should inspire contemporary African leadership. Interestingly, such an approach matches with more critical (anthropological) perspectives on identity formation in an African context that underline the processual character of 'Africanness' (e.g. Appiah, 1992 and Nyamnjoh, 2003). It implies a more dynamic attitude, distancing from pristine notions of a supposedly unchanged nature of what constitutes 'Africanness' throughout times. Instead, African identity formation is seen as a more or less open-ended process, without a priori images of what Africans should feel like, should be like, or would have been like in pre-colonial times. African identity formation thus defined also implies an increased awareness of processes of cultural diffusion within Africa and on a global level.

Afrocentric discourse started in South Africa with an over-emphasis on notions of humaneness and democratisation. Several years later, it seems to have taken on also slightly tougher connotations.

\section{'HARD-NOSED DECISIONS'}

Ever since 'African management' was established as a 'new concept' in South Africa's management, some authors also referred to it as the 'ubuntu style of (participatory) management' (Prinsloo, 1996;1998) or 'the ubuntu system of management' (Versi, 1998). Also, the term 'African management movement' was used, sometimes with a sense of admiration or - quite the opposite in a rather disdainful way (Thomas \& Schonken, 1998 and Maier, 2002), or 'ubuntu movement' (Jackson, 2004:250). The management 'ubuntu movement' has grown bigger than just the organisers and participants of the SAMP workshop in 1992, and bigger than the readership of the books that resulted from it. Marketing specialist and consultant Mike Boon for instance has also been associated with the 'ubuntu community' in management. Boon believes in 'interactive leadership', which illustrates his interpretation of the 'African way': sharing of ideas, group

\footnotetext{
${ }^{15}$ Source: www.reuelkhoza.co.za [accessed 22 July 2005].

16 'African Leadership Forum', 16 October 2003, Sandton Convention Centre, Johannesburg.
} 
discussions, genuine communication, and consultation. At the end of the day however, the leader has to take a decision, as everybody expects him or her to do so. Boon introduced other 'African terms' (in Zulu) in relation to management, such as 'umhlangano', which would mean discussion group or interactive forum. The emphasis on group discussion, interaction and consultation does however not imply that decision-making is always a very sociable affair: '...$y e s$, it is lonely being a leader.' ${ }^{17}$ Others also recognise a tough side to 'ubuntu'.

'Ubuntu is not soft', Mrs Mpo Letlape stated resolutely at an IODT conference. ${ }^{18}$ Mrs Letlape is Managing Director of Eskom's Human Resources Division and she is a member of the elevenmember Executive Committee. Letlape emphasised the need for 'high performance', stating that 'management should not be too lenient on poor performers'. Reuel Khoza has also regularly underlined the need for bold leadership and hard-nosed decisions in an 'African management'/'African (Business) Leadership' perspective: 'The most effective leader of all is democratic, who has a knack for listening, but who at the end, is able to give bold leadership and make hard-nosed decisions'. ${ }^{19}$ He added: 'A good leader is someone who is able to manage the paradox of listening and consulting, then acting boldly' and 'The only counter to [...] the tendency to autocracy is robust debate'. In what sense is all this 'African'? Khoza: 'The more attention to build leadership focus on being rather than doing, the more likely the African concept of leadership will come to the fore'. Not only Eskom, but also MTN (a multi-national GSM cellular network operator), CIDA City Campus (also called the 'Ubuntu University' that has drawn a good deal of media attention) and First National Bank seem to sympathise with and invest in 'African management'/'African (Business) Leadership' or similar concepts. This year several new 'Indigenous African Knowledge and Management Publications' were released and reprints of bestselling books that were originally published in 1995 and 1996, indicating a continuing (or renewed) interest in 'African management' discourse (e.g. Mbigi, 2006 and Broodryk, 2006).

In the following final sections, it is attempted to develop an interpretative viewpoint on 'African management' discourse, focussing on cultural diversity and ethnicity in organisations and how these issues can be approached. Cherishing cultural diversity in South Africa is discursively linked to the notion of 'Africa's cultural heritage'.

\section{CULTURAL DIVERSITY AND ETHNICITY IN RELATION TO ‘AFRICA'S CULTURAL HERITAGE’}

'African management' is generally described in terms of collectiveness, with communalism mostly believed to be a better term. In this light, cultural diversity is cherished as an enrichment to society and organisations, as long as it would imply mutual respect and integration, and not in the illusory sense of a multicultural 'living apart together'. Eskom's HR Managing Director Mpho Letlape explained the notion of 'cultural diversity' in relation to 'Africa's cultural heritage' in terms of adapting oneself to specific cultural situations, suggesting a flexible attitude, while Eskom's Joe Matsau described it as 'understanding each other'. ${ }^{20}$ 'African management' proponents tend to interpret this as an aspect of 'Africa's cultural heritage', a willingness to get to know the other. The assumption is that a variety of approaches could thrive in a culturally diverse environment, with everybody learning and benefiting from each other, under the reign of an African leadership that is constituted by all those different ethnic and cultural groups together. ${ }^{21}$ In a humane, Afrocentric style of management and organisation, people would not have to feel alienated but be free and 'at home', belonging to a larger community, recognising and harnessing a collective cultural heritage. Mostly, 'African management' thinkers would not envisage a 'take-over', but a rightful place in the world of the South African business world: integration - 'fusion' and 'synthesis' are other expressions used in this regard - is a characteristic that suggests that an Afrocentric orientation could be incorporated into a greater whole. Conversely, an Afrocentric orientation allows other perspectives, be they 'Eurocentric', 'western', 'foreign' or 'modern'. Eventually a synthesis between 'African' and 'western' concepts and perspectives is envisaged, an eclectic mixture of 'traditional' and 'modern' concepts and perspectives. In this construction of self-understanding, history has a

\footnotetext{
${ }^{17}$ Interview with Mike Boon on 13 April 2004.

18 'Becoming Global Power Company of the Year' by Mpho Letlape at the $5^{\text {th }}$ Annual Conference of the Institute for Organisation Development and Transformation, Boksburg, 12 November 2003.

19 'Prince of Paradox. Reuel Khoza and the quest for a working model of leadership in the African context' Financial Mail 25 July 2003

${ }^{20}$ Interview with Joe Matsau, Eskom's Managing Director of the Corporate Communications Division on 11 March 2004.

${ }^{21}$ Interview with Eric Mafuna, Executive Director of consultancy bureau Africa Now on 11 May 2004.
} 
central place. 'African management' discourse can be seen as vehicle for a political project, or - in the words of Terry Eagleton - 'a form of political critique':

...the fundamental political question is that of demanding an equal right with others what one might become, not of assuming some fully-fashioned identity, which is merely suppressed. (Bhabha, 1994:345) ${ }^{22}$

Such cultural strategy may arise 'at points of social crises' - in which terms South Africa's transition period might be characterised - when 'identity is claimed either from a position of marginality or in an attempt at gaining the centre: in both senses: ex-centric' (Bhabha, 1994:254). Although Homi Bhabha did not specifically have the South African situation in mind, his words seem quite applicable. The majority of the South African population come from a marginalised position, and there is certainly an attempt 'at gaining the centre'.

Whereas cultural diversity is viewed positively in Afrocentric management discourse, and thus made explicit in various ways, there seems to be an overall tendency in South Africa to view the issue in a rather neutral or instrumental way. Although in dominant management discourse, cultural diversity and ethnicity are in fact being acknowledged, at the same time they tend to be deemphasised. Arguably, this contrasts remarkably with Afrocentric management perspectives.

\section{VIEWING CULTURAL DIVERSITY AND ETHNICITY IN SOUTH AFRICAN ORGANISATIONS}

Two South African senior researchers, Adèle Thomas and Mike Bendixen, found that 'effective management culture is independent of race' (Thomas \& Bendixen, 2000:517) ${ }^{23}$ To their own astonishment, so it seemed, the authors concluded from a comparison of culture dimensions between ethnic groups in the workplace that at a managerial level there are striking similarities. In addition, there would also be striking similarities between Dutch, British and American 'cultures' and that of South African managers. ${ }^{24}$ Tentatively they concluded that 'the effect of ethnicity on management culture is minimal' and 'there is no dependence between race and management culture' (Thomas \& Bendixen, 2000:515). They were inclined to consider ethnicity and cultural diversity in the South African workplace, including managerial positions, as 'something to be valued', at least something to be better understood, and not something that would necessarily hinder competitiveness:

...the realisation of fully integrated and ethnically diverse management strata will not inhibit corporate competitive performance... (Thomas \& Bendixen, 2000:516)

In view of 'the plethora of ethnic groups' in the South African workplace, it is important to understand the different values that people bring to the organisation. Essentialist notions about 'African culture' and about black people specifically, assuming for instance that black managers generally tend to be less individualistic than their white colleagues in similar positions, seem to be pretty persistent in South Africa. However, a sense of appreciation seems to come into sight with regard to ethnicity and cultural diversity in organisations. The latter is perhaps indicative of a (ideological) transition; a move from a doctrine of white supremacy and 'corporate multiculturalism', in which (black) Africans are deemed 'different' whereas 'whiteness' is not treated as a form of ethnicity, into a sort of (left) liberal multiculturalism. Liberal multiculturalism contends that there is 'a natural sameness' between ethnic groups. In this view, eventually anyone can compete equally in the capitalist marketplace, if measures are taken to create equal social and educational opportunities. Left liberal multiculturalism reveals a tendency to essentialise cultural differences and exoticise 'otherness' while ignoring the social and historical construction of difference 'that is constitutive of the power to represent meanings' (McLaren, 1994:52). In South Africa's academic community, Frank Horwitz seems to be well aware of the importance of the latter. He indeed considers 'cultural diversity' in South African firms as a competitive advantage, but does not wish to refute the specific historical background of the given situation (Horwitz, Bowmaker-Falconer \&

\footnotetext{
${ }^{22}$ Citation from Eagleton, T. (1990) 'The Ideology of the Aesthetic' Oxford: Blackwell, pp. 414.

${ }^{23}$ Adèle Thomas was director of WBS up to mid-2004 approximately.

${ }^{24}$ Following Ulf Hannerz, the author is critical of the idea of well-bounded coherent 'national cultures' (Hannerz 1996: 23).
} 
Searll, 1996 and Horwitz, Browning, Jain \& Steenkamp, 2002) ${ }^{25}$

In an 'African management' perspective, cultural (ethnic) difference tends to be accentuated. The aspect of cultural diversity even becomes overtly dramatised, for example in so-called diversity and transformation workshops. Lovemore Mbigi and Mike Boon for instance tend to provoke workshop participants to let them speak out about their perceptions and feelings towards others - 'others' in such a case would mostly mean other 'other ethnic groups', mostly reduced to gross categories of 'black' and 'white'. They are encouraged to express suspicion and grievances, talk about daily experiences at work, discriminatory practices even, or practices perceived as such. This may turn into very intense, emotional, and explosive proceedings. Sometimes, participants experience such sessions as rude, insensitive, and unnecessarily offensive. Only with mastery facilitation, things will not go terribly out of hand. Such skills supposedly depend more on personal characteristics than on the very Afrocentric management ideas that are made public at such occasions. This approach differs from the perception that a cultural, ethnic identity is merely a neutral factor that happens to exist in South African organisations, but which would not negatively affect business performance. The message of workshop facilitators, such as Boon and Mbigi, could be read in political terms: do not sweep 'ethnicity' under the managerial carpet. Participants may disclose stories untold and air anguish and resentments, and thus discursively room is created for 'the silenced' to speak out, while those in powerful positions are made to listen, and respond.

A fair assessment of Afrocentric management discourse should include critical aspects. Several authors have commented on the use of stereotypes, opportunistic motives and the commodification of 'ubuntu'. These critiques are discussed in the following section.

\section{OPPORTUNISTIC USE OF 'UBUNTU'?}

'African management' proponents have been heavily criticised for their 'maximalist perspective' (Human, 1996). The main critique concerns the reference to stereotypes of 'national cultures', which is judged as harmful. Rather, cultural sensitivity trainers should focus on individual attitudes and behaviours of managers and other employees, instead of taking the assumed characteristics of members of a 'national culture' or ethnic group as point of departure. In this viewpoint, it would be preferable to apply the concept of 'situational adaptability': appreciating all relevant facets that together constitute a person's identity, then make a selection and consider only characteristics that are situationally relevant in a given particular organisational context. This assessment is fairly nuanced and justified in principal, but overlooks a crucial aspect, namely the therapeutic potential of such emotional, dramatising approach under the pretext of 'African management' interventions.

Various commentators have also seriously questioned concepts that allude to 'African culture' and 'traditional values'. Some assert that South Africa is nothing but a cultural outpost of Europe, a 'western cultural ghetto' that widely accepts western, global cultural values, perhaps just adding some kind of 'African spin' to it. There would be 'not much specific content' to African cultural system (Bernstein, 2002:200). Likewise, an 'African management' technique based on the concept of 'ubuntu' would not be capable of providing any useful guidelines how to function in a modern company situation (Bernstein, 2002:206).

Apparently, there are reasons for an 'ubuntu industry' to exist in South Africa. It could be curiosity, a fascination with exotic forms of 'ancient wisdom', a romanticised past and a longing for indigeneity and purity. From this perspective, one could easily view 'African management' with scepticism and draw attention to the opportunistic use of such concepts, highlighting commercial aspects, and power relations. Similarly, the idea of the African Renaissance is seen as an ideological tool, by which the interests of a rising black capitalist elite are generalised 'to make them that of the people', calling for 'ubuntu' while insisting on 'very ruthless and paternalistic labour policies' (Maloka, 1997:42).

Corporate South Africa has proved [...] accepting of [...] more authentically 'African' concepts that are woven into the African renaissance. Ubuntu is one of them. Essentially, an ethos of reciprocity and mutual aid, it centers on the idea that people realize themselves

\footnotetext{
${ }^{25}$ Frank M. Horwitz is Professor of Business Administration and Director of the Graduate School of Business at the

University of Cape Town (source: http://www.gsb.uct.ac.za [accessed 18 July 2006]).
} 
through others. Motivational speakers and consultants, corporate human resource planners and advertising agencies eagerly assimilate the concept into their attempts to help modernize and revitalize South African capitalism. The African renaissance vision is evidently hospitable to such opportunism. (Marais, 2001:250)

In this perspective, the 'ubuntu' concept is judged as highly opportunistic, as it suggests togetherness and belonging, while in fact it serves capitalist business interests. Who said that 'ubuntu' as transformed in the course of time by colonialism, apartheid, globalisation, and eventually by 'African management' discourse, would be necessarily opposed to capitalist development? As demonstrated hereunder, 'African management' advocates flourish quite well in a capitalist business environment.

\section{THE 'MIXED MARRIAGE’ OF ‘AFRICAN MANAGEMENT' AND CAPITALISM}

If 'ubuntu' means humanity in the broadest sense, would it not clash with capitalism that is characterised by surplus value created by exploitation of human labour? Let there be no mistake, 'African management' and capitalist development are discursively not considered contradictory. As a management philosophy that emerged in a capitalist environment, 'African management' was never publicised as explicitly anti-capitalist, socialist, or in any similar ideologically loaded terms. In essence, it is not assumed to be antagonistic to capitalism, but to be critical of certain management practices in organisations under post-apartheid capitalism. In a paradoxical way, 'African management' is opposed to 'Eurocentric management' while simultaneously seeking a 'mixed marriage' into a multiracial family: the reconciliatory African wants to marry a mean yet attractive European or American bride, to live happily ever after in a peaceful and prosperous South Africa.

As a concept largely appropriated by Afrocentric management consultants, 'ubuntu' is inherently part of South Africa's post-apartheid capitalist economy. It has become a commodity in itself. Moreover, the link between being black African and being wealthy has become accepted. Has another taboo on 'race' been broken? The ideology of consumer capitalism is now accessible to everyone. Saki Macozoma, one of the Black Economic Empowerment 'typhoons' commented, when evading critical questions on the 'self-enrichment' of a small elite of black entrepreneurs: 'If South Africa is to be a capitalist economy, it cannot then say in the same breath "if someone is black, it is not OK to accumulate wealth'. ${ }^{26}$

Material wealth is not considered morally unacceptable in an 'African management' perspective, although one should not confuse the latter with BEE viewpoints. Nevertheless, Afrocentric management philosophy claims to defy a society that is not sustainable and not equitable, a society that is not spiritual and lost its cultural identity. Furthermore, it seeks to challenge an economy that is not sufficiently creative and innovative. This paradox explains that 'African management' advocates continue to have a mission, while not touching upon the foundations of capitalist development. One may question whether 'African management' advocates are to blame for a continuing unjust distribution of wealth and income. Is it fair to accuse them of 'mystifying' relations between labour and capital because of their appeal to Afrocentric notions of mutual solidarity and togetherness? This would assume a rather reductionist assessment of social and economic relations in South African society, but it is undeniable that a few 'African management' consultants seem to prosper quite well in a capitalist setting.

Now several characteristics and critiques with regard to 'African management' discourse have been discussed, it is a challenge to consider possible implications to managers and entrepreneurs in South Africa. In essence, it is recommended to bear in mind the meaningful insights that were raised at CBM's renowned 'Broederstroom' consultations back in 1988, from which indirectly also 'African management' philosophy emerged. Some of these insights may still be valid today.

\section{IMPLICATIONS FOR MANAGEMENT AND ORGANISATION}

Qualitative research on the emergence and evolvement of Afrocentric management perspectives reveals that the promotion of Afrocentric viewpoints may encourage processes of reflection and

\footnotetext{
${ }^{26}$ Saki Macozoma, chief executive of New Africa Investments Limited (NAIL) was chosen as 'Business Leader of the

Month' ('The deal-maker' Sunday Times Business Times 5 July 2003).
} 
identity formation among employees and management in various ways. It does by no means aim at a radical 'take-over' of existing management practices and leadership styles by some sort of an exclusivist Africanist model, as some might fear. Rather it seeks integration and recognition, resulting in an appreciation of 'other' views and different value orientations in respect to management and organisation. In principle, this could result in improved relationships within organisations. There should however be sufficient levels of trust and space for people to speak out and air their resentments and aspirations, so insightful 'hidden messages' can surface.

Such conversations tend to be rather emotional, with which in particular masculine type of managers may feel quite uncomfortable and which they may therefore judge as 'irrational' or 'costing too much time'. It indeed takes time, money and courage, but the effects on organisational culture may be more entrancing than sceptics about Afrocentrism, about (the commodification of) 'African culture' and 'indigenous knowledge' would expect. Having said this, the qualities of organisational culture depend on many interacting factors. A series of workshops and plenary debates remains of course a relatively small feature in this complex whole.

In the late 1980s, CBM made painfully clear that South African entrepreneurs seriously suffered from 'political and social illiteracy'. Is this something that they still would like to be accused of today? Have CBM's lessons been forgotten? A suggestion for management and organisation is to undertake an active strategy to allow and facilitate a broad-based - possibly 'African management'style - dialogue, once problems relating to notions of for instance 'ethnicity', 'alienation' and 'discrimination' are identified as 'taboo issues' within the organisation. Furthermore, this strategy may precisely help identifying such taboos as problematic to the functioning of the organisation. This could be a meaningful alternative to 'neutralising' or consciously avoiding these precarious issues and pretending to uphold a 'normal' global business outlook at all cost. Nevertheless, to achieve reconciliation at corporate level, to overcome traumas of the past and feelings of (cultural) 'alienation' among employees, an 'African management' philosophy may be instructive, but it does undoubtedly not provide the one and only possible strategy in this respect.

\section{CONCLUSION}

A balanced analysis of the 'African management' and 'ubuntu' concepts should be critical of their strategic use, the commodification aspect, and the emphasis on stereotypical representations of national and ethnic 'cultures'. It would also have to consider positive functions. A strong normative concept as 'ubuntu' has the potential to generate a reservoir of imaginative power. Its particular appeal lies in the encouragement of a sense of belonging and (African) identity in-the-making, selfconsciousness, liberation, and entrepreneurship - or 'freedom of enterprising', as Albert Koopman would rather phrase it. Perhaps, Eskom is a case in point here, although it remains to be seen how values associated with 'ubuntu' actually work out in day-to-day management practices.

The potential restorative effects of so-called 'diversity and transformation workshops' as conducted by 'African management' advocates, may help to become aware of unheard voices, hidden meanings, and meaningful cultural expressions. Controversy and criticism around 'African management' viewpoints may possibly facilitate instructive dialogues to break taboos in modern organisational contexts, especially where 'modernity' meets 'traditionalism' ${ }^{27}$ A strategy to give room to such discussions rather than minimise these may be preferable to simply wiping 'taboo issues' from the managerial agenda or imposing prearranged corporate values. ${ }^{28}$ Eventually, a process of (non-essentialist) identity formation may emerge in organisations, in which a long history of 'unfree labour' and South Africa's considerable cultural and ethnic diversity are appreciated.

\section{REFERENCES}

Alberts R, Coetsee B, Coleman C, Eloff T, Marsden D \& Payne R. (Eds.). 1993. Managing change. A guide to the role of business in transition. Johannesburg: Ravan Press.

\footnotetext{
${ }^{27}$ Franks, P.E. (forthcoming) 'Managing in a rural context: Notes from the frontier' in Van den Heuvel, H.; Mangaliso, M. and Van de Bunt, L. (eds.) Prophecies and Protests: Ubuntu in Glocal Management.

${ }^{28}$ At a conference of the Industrial Relations Associations of South Africa in 2000, Johann Stimie proposed a strategy to 'thematize rather than minimize racial issues' that would create a possibility to facilitate a more meaningful change towards removing 'racial barriers' in organisations.
} 
Appiah KA. 1992. In my father's house. Africa in the Philosophy of Culture. New York: Oxford University Press.

Bernstein A. 2002. Many globalizations. Cultural diversity in the contemporary world (Eds Berger \& Huntington). Oxford: Oxford University Press.

Bhabha HK. 1994. The location of culture. London, New York: Routledge.

Binedell N. 1994. In African management. Philosophies, Concepts and Applications (Eds Christie, Lessem \& Mbigi). Randburg: Knowledge Resources.

Broodryk J. 2006. UBUNTU: Management Philosophy. Exporting ancient African Wisdom into the Global World. Randburg: Knowledge Resources.

Christie P, Lessem R \& Mbigi L. (Eds.) 1994. African management. Philosophies, Concepts and Applications, Randburg: Knowledge Resources.

Dickinson D. 2005. Beyond the Apartheid Workplace. Studies in Transition (Eds Webster \& Von Holdt). Pietermaritzburg: University of KwaZulu-Natal Press.

Hannerz U. 1996. Transnational connections. Culture, people, places. London: Routledge.

Horwitz FM, Bowmaker-Falconer A \& Searll P. 1996. International Journal of Manpower, 17:134151.

Horwitz FM, Browning V, Jain H \& Steenkamp AJ. 2002. International Journal of Human Resource Management, 12:1105-1118.

Human L. 1996. International Journal of Manpower, 17:46-64.

Hunt J \& Lascaris R. 1998. The South African dream. Halfway House: Zebra Press.

Jackson T. 2004. Management and change in Africa. A cross-cultural perspective. London, New York: Routledge.

Khoza R. 1994. In African Management. Philosophies, concepts and applications (Eds Christie, Lessem \& Mbigi). Randburg: Knowledge Resources.

Khoza R. 2003. The Role of African Leaders and Professionals in this current phase of transformation. Eskom.

Koopman AD. 1991. Transcultural management. How to unlock global resources. London: Blackwell Publishers.

Koopman AD, Nasser ME \& Nel J. 1987. The Corporate Crusaders. Johannesburg: Lexicon Publishers.

Lascaris R \& Lipkin M. 1993. Revelling in the wild: business lessons out of Africa. Cape Town: Human and Rousseau.

Lessem R \& Nussbaum B. (Eds.). 1996. Sawubona Africa. Embracing four worlds in South African management. Sandton: Zebra Press.

Maier C. 2002. Leading diversity - a conceptual framework. St. Gallen: University of St. Gallen.

Maloka E. 1997. The African Communist, 37-43.

Mamdani M. 1996. Citizen and Subject. Contemporary Africa and the legacy of late colonialism, Kampala: Kampala Fountain Publishers. 
Mangaliso MP \& Nkomo SM. 2001. Academy of Management Executive, 15: 8-15.

Marais H. 2001. South Africa. Limits to change. The political economy of transition. University of Cape Town: Cape Town Press.

Mbembe A. 2002. Public Culture, 14:239-273.

Mbigi L. 1994. In African management. Philosophies, Concepts and Applications (Eds Christie, Lessem \& Mbigi). Randburg: Knowledge Resources.

Mbigi L. 2006. The Spirit of African Leadership. Randburg: Knowledge Resources.

McLaren P. 1994. In Multiculturalism (Ed Goldberg). Oxford: Blackwell Publishing.

Nasser ME \& Vivier FJ. 1995. Mindset for the new generation organisation. How leading South African companies create counter-trend performance in turbulence. Report of Project New Generation Economy. Cape Town: Juta \& Co.

Nel C. 1988. Leadership SA, 7:35-38.

Nyamnjoh FB. 2003. Philosophia Africana, 6:1-18.

Prinsloo ED. 1996. In Decolonizing the mind. Proceedings of the Second Colloquium on African Philosophy (October 1995) (Ed, Malherbe). Research Unit for African Philosophy, Department of Philosophy. Pretoria:University of South Africa.

Prinsloo ED. 1998. In Philosophy from Africa. A text with readings (Eds, Coetzee \& Roux). Halfway House: International Thomsom Publishing.

Terreblanche S. 2002. A history of inequality in South Africa 1652-2002.

Pietermaritzburg/Sandton: University of Natal Press \& KMM Review Publishing Company Pty.

Thomas A \& Bendixen M. 2000. Journal of International Business Studies, 31:507-519.

Thomas A \& Schonken JS. 1998. South African Journal of Business Management, 29:53-66.

Vail L. (Ed.). 1991. The Creation of Tribalism in Southern Africa. Berkeley: University of California Press.

Versi A. 1998. In African Business, 7.

Webster E \& Von Holdt K. 2005. In Beyond the Apartheid Workplace. Studies in Transition Pietermaritzburg: University of KwaZulu-Natal Press. 